\title{
Post-stenotic saccular aneurysm of the left descending coronary artery: silent and life-threatening disarray
}

\author{
Gian Piero Carboni, ${ }^{1}$ Pietro Sedati ${ }^{2}$ \\ ${ }^{1}$ Department of Nuclear Cardiology, Università Campus Bio-Medico, Rome, Italy \\ ${ }^{2}$ Department of Radiology, Università Campus Bio-Medico, Rome, Italy
}

Correspondence to Professor Gian Piero Carboni, g.carboni@unicampus.it

\section{DESCRIPTION}

A 77-year-old man presented to us with atypical chest pain, hypertension, hypercholesterolaemia and ST changes on the ECG lateral leads and negative cardiac enzymes. The presence of an intermediate pretest probability of coronary artery disease suggested performing a coronary tomography (CT). The scan documented calcium lesions in the left descending (Lad) and left circumflex coronary arteries and a saccular coronary artery aneurysm (CAA) adjacent to a calcium lesion in the Lad (figure 1, video 1). An invasive coronary angiography (ICA) demonstrated that only the calcium lesion adjacent to the CAA was associated with significant stenosis of the Lad. In this patient, degenerative, congenital, inflammatory, infectious, toxic and traumatic causes were excluded by laboratory investigations.

The frequency of CAA varies widely, from $0.3 \%$ to $5 \%$, and complications include thrombosis, embolic phenomena, arteriovenous fistulisation, spasm, rupture with haemopericardium and sudden death. ${ }^{1}$ A prerequisite to

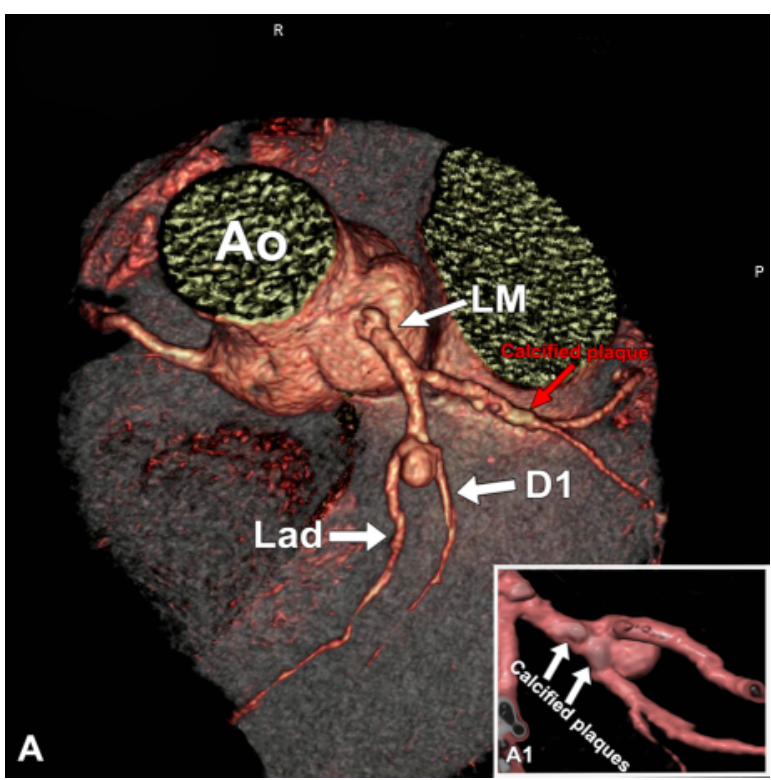

Figure 1 (A) CTA shows a saccular coronary artery aneurysm in the left anterior descending (Lad) artery at the bifurcation of the first diagonal branch (D1) and a calcium plaque (red arrow) in the left circumflex artery. LM refers to the left main artery, and Ao refers to the aorta. (A1) Two calcium plaques in the Lad. The distal plaque is located in the neck of the aneurysm.

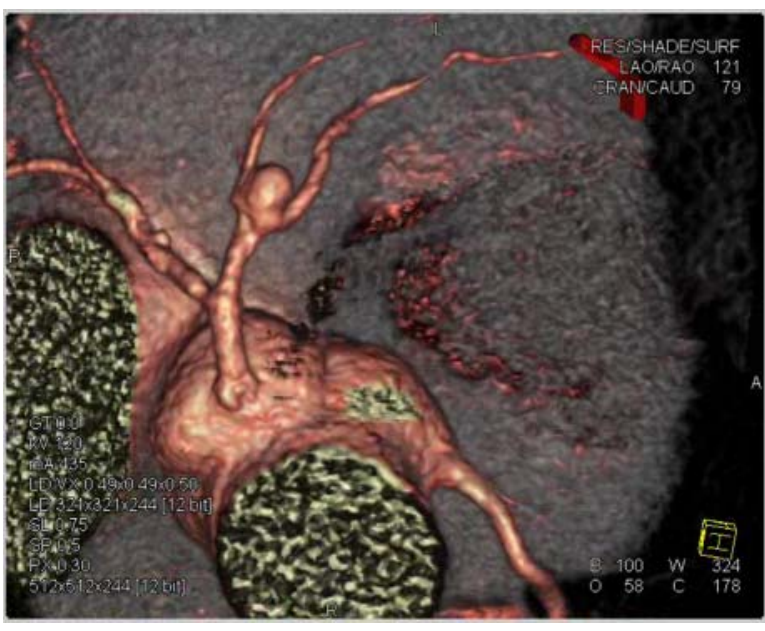

Video 1 The cine coronary tomography gives an anatomical picture of the coronary vessels, including the location of the aneurysm and calcium plaques.

CAA formation is the presence of erosion, ulceration and haemorrhage in the tunica media of the related vessel, while formation of a post-stenotic CAA is determined by turbulent blood flow, which causes wall damage. ${ }^{2}{ }^{3}$ The patient's setting suggested that the LAD post-stenotic CAA aetiology was a direct extension of the intimal atherosclerotic process in the tunica media of the vessel. An ICA revealed the severity of Lad obstruction, while CT displayed the CAA diameter and the exclusion of intraluminal thrombi. In this patient, combined CT and ICA were followed by successful aneurysm excision and surgical revascularisation of the Lad with an internal mammary artery.

\section{Learning points}

- Conventional coronary angiography may underestimate the size of the saccular coronary artery aneurysm (CAA) or not even detect the CAA if it is occluded or contains substantial thrombi or plaque. A combination of coronary tomography and invasive coronary angiography is therefore a determinant for saccular CAA detection.

- Conservative measures consist of attempts to prevent thromboembolic complications with anticoagulant therapy and administration of antiplatelet drugs. 


\section{BMJ Case Reports}

\section{Competing interests None.}

Patient consent Obtained.

\section{REFERENCES}

1. Díaz-Zamudio M, Bacilio-Pérez U, Herrera-Zarza MC, et al. Coronary artery aneurysms and ectasia: role of coronary CT angiography. Radiographics 2009;29:1939-54.
2. Tunick PA, Slater J, Kronzon I, et al. Discrete atherosclerotic coronary artery aneurysms: a study of 20 patients. J Am Coll Cardiol 1990;15:279-82.

3. Barettella MB, Bott-Silverman C. Coronary artery aneurysms: an unusual case report and a review of the literature. Catheter Cardiovasc Diagn 1993;29:57-61.

This pdf has been created automatically from the final edited text and images.

Copyright 2012 BMJ Publishing Group. All rights reserved. For permission to reuse any of this content visit http://group.bmj.com/group/rights-licensing/permissions.

BMJ Case Report Fellows may re-use this article for personal use and teaching without any further permission.

Please cite this article as follows (you will need to access the article online to obtain the date of publication)

Carboni GP, Sedati P. Post-stenotic saccular aneurysm of the left descending coronary artery: silent and life-threatening disarray. BMJ Case Reports 2012;10.1136/bcr-2012-007181, Published XXX

Become a Fellow of BMJ Case Reports today and you can:

- Submit as many cases as you like

- Enjoy fast sympathetic peer review and rapid publication of accepted articles

- Access all the published articles

- Re-use any of the published material for personal use and teaching without further permission

For information on Institutional Fellowships contact consortiasales@bmjgroup.com

Visit casereports.bmj.com for more articles like this and to become a Fellow 